\title{
High-resolution microparticle profiles at NorthGRIP, Greenland: case studies of the calcium-dust relationship
}

\author{
Urs RUTH, ${ }^{1,2}$ Dietmar WAGEnBACH, ${ }^{1}$ Matthias BIGLER, ${ }^{3}$ Jørgen P. STEFFEnSEN, ${ }^{4}$ \\ REgine RÖTHLISBERGER, ${ }^{3}$ Heinz MILLER ${ }^{2}$ \\ ${ }^{1}$ Institut für Umweltphysik, Universität Heidelberg, Im Neuenheimer Feld 299, D-69120 Heidelberg, Germany \\ E-mail: urs.ruth@urz.uni-heidelberg.de \\ ${ }^{2}$ Alfred-Wegener-Institut für Polar-und Meeresforschung, Columbusstrasse, D-27568 Bremerhaven, Germany \\ ${ }^{3}$ Climate and Environmental Physics, University of Bern, Sidlerstrasse 5, CH-3012 Bern, Switzerland \\ ${ }^{4}$ Department of Geophysics, The Niels Bohr Institute for Astronomy, Physics and Geophysics, University of Copenhagen, Juliane Maries Vej 30, \\ DK-2100 Copenhagen, Denmark
}

\begin{abstract}
A novel flow-through microparticle detector was deployed concurrently with continuous flow analyses of major ions during the North Greenland Icecore Project 2000 field season. The easy-handling detector performs continuous counting and sizing. In this deployment the lower size-detection limit was conservatively set to $1.0 \mu \mathrm{m}$ equivalent spherical particle diameter, and a depth resolution of $\leq 1 \mathrm{~cm}$ was achieved for microparticle concentrations. The dust concentration usually followed the $\mathrm{Ca}^{2+}$ variability. Here results are presented from an inspection of the $\mathrm{Ca}$ /dust mass ratio in 23 selected intervals, $1.65 \mathrm{~m}$ long each, covering different climatic periods including Holocene and Last Glacial Maximum (LGM). A $\left(\mathrm{Ca}^{2+}\right) /($ insoluble dust) mass ratio of 0.29 was found for the Holocene and 0.11 for LGM. Changes to the $\mathrm{Ca} /$ dust ratio occur on an annual to multi-annual time-scale exhibiting the same pattern, i.e. a lower $\mathrm{Ca} /$ dust ratio for higher crustal concentrations. Moreover, the $\mathrm{Ca}^{2+}$ /dust ratio may increase significantly during episodic events such as volcanic horizons due to enhanced dissolution of $\mathrm{CaCO}_{3}$. This calls into question the notion of deploying $\mathrm{Ca}^{2+}$ as a quantitative mineral dust reference species and shows the importance of variable source properties or fractionating processes during transport and deposition.
\end{abstract}

\section{INTRODUGTION}

The atmospheric mineral dust load, mainly composed of insoluble mineral particles, is an important part of Earth's climatic system as it is involved in direct and indirect radiative forcing processes (e.g. Tegen and Fung, 1994). Equally, the amount, size distribution and composition of dust deposited on polar ice sheets may hold valuable information about both positions and climatic conditions of source areas, as well as about long-range transport and deposition processes (Biscaye and others, 1997; Fuhrer and others, 1999). Over the last climatic cycle, Greenland as well as Antarctic mineral-dust records exhibit changes on a huge dynamic range (e.g. Hansson, 1994; Steffensen, 1997; Petit and others, 1999). In Greenland these changes occurred very rapidly and coincided with changes in $\delta^{18} \mathrm{O}$ at rapid climatic transitions within the last Pleistocene, as has been inferred from high-resolution measurements of $\mathrm{Ca}^{2+}$ and electrical conductivity measurements (ECM) on the Greenland Icecore Project (GRIP) and Greenland Ice Sheet Project 2 (GISP2) ice cores (Taylor and others, 1997; Fuhrer and others, 1999).

The concentration of $\mathrm{Ca}$ ions $\left(\mathrm{Ca}^{2+}\right)$ is often used as a proxy parameter for total mineral dust in ice cores, as it represents the major part of the readily dissolved fraction of the dust aerosol. But the soluble proportion of dust is not constant over different climatic periods (Steffensen, 1997), so using $\mathrm{Ca}^{2+}$ as a proxy may give a distorted view of the total dust concentration. However, dust measurement techniques also have disadvantages: only low-resolution profiles or selected continuous sections have been measured for insoluble microparticles using the well-established Coulter counting technique (e.g. Steffensen, 1997) since that requires extensive sample preparation and handling; and high-resolution continuous dust measurements using $90^{\circ}$ laser light scattering off meltwater (Hammer and others, 1985) or off ice (Ram and Koenig, 1997) yield no size-distribution information or are difficult to calibrate.

Here we introduce a novel laser sensor device for microparticle measurements deployed for continuous recordings of microparticle concentration and size distribution during the North Greenland Icecore Project (NorthGRIP) 2000 field season. Apart from the methodical aspects, we present and discuss case-studies of the dust concentration focusing on the $\mathrm{Ca}^{2+}$ /dust ratio under inconspicuous conditions as well as in volcanic horizons.

\section{EXPERIMENTAL SET-UP}

During the NorthGRIP 2000 field season, extensive scientific processing was performed shortly after retrieval of the ice core. This included the operation of a warm laboratory for continuous flow analysis (CFA) of $\mathrm{Ca}^{2+}, \mathrm{Na}^{+}, \mathrm{NH}_{4}{ }^{+}, \mathrm{SO}_{4}{ }^{2-}$, $\mathrm{NO}_{3}{ }^{-}, \mathrm{H}_{2} \mathrm{O}_{2}$ and $\mathrm{HCHO}$ concentrations, and of electrolytical conductivity (Röthlisberger and others, 2000). Concurrently, continuous microparticle counting and sizing was performed. Discrete liquid samples were collected at $55 \mathrm{~cm}$ resolution for 


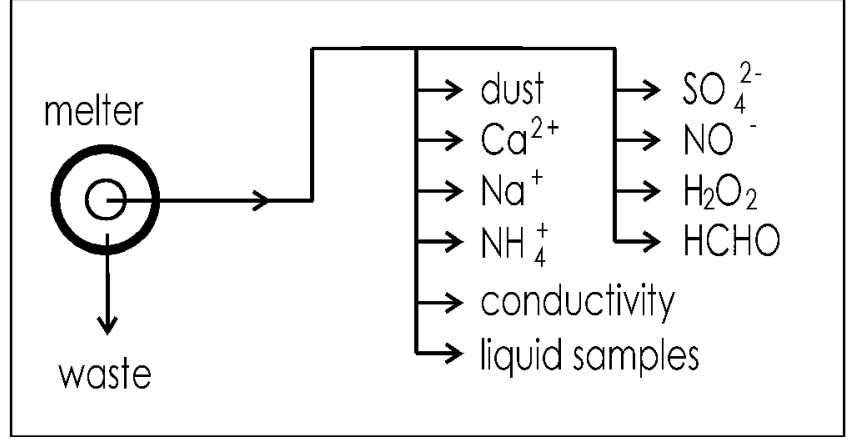

Fig. 1. Flow chart of the analytical set-up ( highly simplified).

subsequent ion chromatography (IC) analysis; and over selected depths, discrete samples for IC and acidity measurements at approximately $6 \mathrm{~cm}$ resolution were also collected by an automatic sampler. The contamination-free sample water for all these analyses was drawn from the inner area of a melt head, where the ice was melted at approximately $4 \mathrm{~cm} \mathrm{~min}^{-1}$. For an overview of the set-up see Figure 1. By these means the core was continuously analyzed from approximately 1400 to $2930 \mathrm{~m}$ depth.

\section{The particle sensor}

The particle sensor for general-purpose laboratory applications is from Klotz GmbH, Bad Liebenzell, Germany, and was specifically modified in collaboration with the Institute for Environmental Physics of the University of Heidelberg (Saey, 1998; Armbruster, 2000). The sample water is pumped through the detection cell, where it is illuminated by a $1.5 \mu \mathrm{m}$ by $250 \mu \mathrm{m}$ wide laser light beam of $670 \mathrm{~nm}$ wavelength. The transmitted light is measured by a photo diode detector (see Fig. 2). When a particle passes through the detection area the transmitted light is attenuated by shadowing and scattering which results in a negative peak of transmitted light. The peak is counted and sorted by height into 32 bins, which can be adjusted to appropriate size intervals.

The interrelation of peak height and particle size is complex. Geometric shadowing is combined with scattering processes, both depending not only on particle volume but also on particle shape, material and orientation. A size calibration was achieved by measuring NorthGRIP ice-core samples from different climatic periods with a Coulter counter and tying the laser sensor measurements of identical depths to the Coulter counter spectra. The calibration measurements showed the particle detection limit to be approximately $0.8 \mu \mathrm{m}$ of spherical equivalent particle diameter. For our measurements, we used $1.0 \mu \mathrm{m}$ diameter as the lower detection limit, to be safely above the level of detector noise.

In our measuring procedure, size distributions were averaged over $1.65 \mathrm{~m}$ intervals. Results including size calibration will be presented elsewhere. The bulk particle number concentration was obtained continuously. To do so, the momentary count rate, converted to an analogue output signal, was recorded and the flow rate regularly measured. The continuously recorded data were later reduced to $1 \mathrm{~mm}$ depth intervals. Dust mass concentrations were inferred by integrating the particle-size distributions obtained for each $1.65 \mathrm{~m}$ section and a material density of $2.7 \mathrm{~g} \mathrm{~cm}^{-3}$; on average, this showed that 1000 count $\mathrm{mL}^{-1}$ are equivalent to $5.6 \mu \mathrm{g} \mathrm{kg}^{-1}$. For each

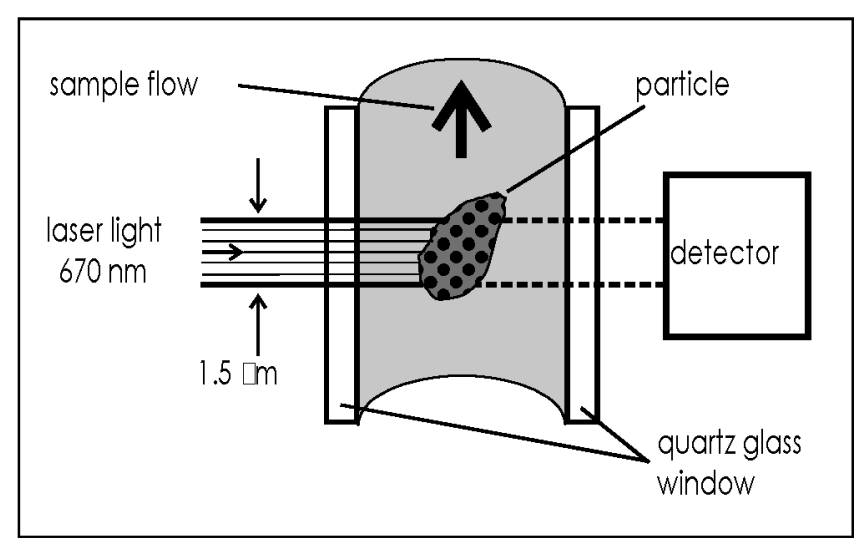

Fig. 2. Detection cell of the laser sensor ( schematic). The cross section of the cell is $230 \mu \mathrm{m} \times 250 \mu \mathrm{m}$; the laser beam is $250 \mu \mathrm{m} \times 1.5 \mu \mathrm{m}$ wide.

section, the relative error of particle mass is about $15 \%$ due to size-calibration uncertainties and varying pump rates.

To avoid coincidence distortion of the measurements, the output signal is cut off by the counter electronics if the counting rate exceeds 4000 particles s $^{-1}$, so the sample flow needs to be decreased for high particle concentrations. However, as flow rates of $<1 \mathrm{~mL} \mathrm{~min}^{-1}$ increase the sample dispersion in the flow system, the sample water from glacial-age ice, which has a considerably higher dust concentration, was diluted with $0.2 \mu \mathrm{m}$ pre-filtered carrier water. Hereby an effective sample flow of approximately $0.15 \mathrm{~mL} \mathrm{~min}^{-1}$ was established while the flow through the sensor was kept above $2 \mathrm{~mL} \mathrm{~min}^{-1}$. The dilution set-up allowed for measuring concentrations of $<15 \mu \mathrm{g} \mathrm{kg}^{-1}$ and $>15000 \mu \mathrm{g} \mathrm{kg}^{-1}$, thus, covering the full dynamic range from Holocene to Last Glacial Maximum (LGM). When used without the dilution system, the detection limit in terms of minimal count rate was about 200 particles $\mathrm{mL}^{-1}$, although this value depends on the flow rate.

As used in our set-up, the depth resolution of the microparticle measurement, expressed as the observed 1/e depth of a step signal, is $\leq 1 \mathrm{~cm}$. It is generally similar to, and often slightly better than, the depth resolution of most other CFA components. Apart from the melt rate, the depth resolution is limited by the conical surface of the melt head, by dead volumes and by longitudinal sample dispersion in the flow system. The impairment in depth resolution from using the dilution system was around $10 \%$. In ice with low particle concentration, the counting statistics also impose a limit on the depth resolution by raising the error of a data point if the number of counts for this data point is low, thus demanding an increase of interval width for each data point. However, the contribution of this statistical effect is more than one order of magnitude less than that of the physical factors mentioned.

Microparticle concentrations are reported here for the size fraction $1.0-11.5 \mu \mathrm{m}$ spherical equivalent diameter in $\mu \mathrm{g} \mathrm{kg}^{-1}$. The mass fraction not measured below $1.0 \mu \mathrm{m}$ accounts for about $10 \%$, assuming a typical lognormal volume distribution.

\section{List of samples}

From the whole NorthGRIP core profile, 23 sections, each $1.65 \mathrm{~m}$ long, are taken for this study. These cover depths from 1420 to $2921 \mathrm{~m}$ and represent various climatic periods including the Holocene and LGM. For all sections, $\delta^{18} \mathrm{O}$ data are already available (personal communication from 
Table 1. Overview of the NorthGRIP core sections used for this study

\begin{tabular}{|c|c|c|c|c|c|c|}
\hline $\begin{array}{l}\text { Mid- } \\
\text { depth }\end{array}$ & $\begin{array}{l}\text { Climatic } \\
\text { period }\end{array}$ & $\delta^{18} O$ & $\begin{array}{c}\text { Mean } \\
\text { dust }\end{array}$ & $\begin{array}{c}\text { Mean } \mathrm{Ca}^{2+} / \\
\text { mean dust }\end{array}$ & $\begin{array}{l}\text { Unusual } \\
\mathrm{Ca}^{2+} / \text { dust }\end{array}$ & $\begin{array}{c}\text { ECM } \mathrm{SO}_{4}^{2} \\
\text { peak peak }\end{array}$ \\
\hline $\mathrm{m}$ & & $\%$ & $\mu \mathrm{g} \mathrm{kg}^{-1}$ & & & \\
\hline
\end{tabular}

\begin{tabular}{cccccccc}
\hline 1424.8 & hol & -35.87 & 44 & 0.29 & - & na & - \\
1441.3 & hol & -36.04 & 57 & 0.29 & - & na & - \\
1459.4 & hol & -36.74 & 58 & 0.17 & + & na & + \\
1479.2 & hol & -38.45 & 99 & 0.22 & - & na & + \\
1486.9 & hol & -36.60 & 48 & 0.24 & - & na & - \\
1627.7 & c-1/2 & -42.07 & 1200 & 0.16 & + & + & + \\
1642.6 & c-1/2 & -42.05 & 1347 & 0.17 & + & + & + \\
1688.8 & c-1/2 & -42.73 & 1318 & 0.16 & + & + & + \\
1716.8 & c-1/2 & -41.15 & 1353 & 0.15 & + & + & + \\
1805.9 & LGM & -43.76 & 5589 & 0.14 & - & - & + \\
1825.7 & LGM & -43.25 & 5373 & 0.11 & - & - & - \\
1855.4 & LGM & -43.00 & 1337 & 0.14 & + & + & + \\
1895.0 & c-4/5 & -44.16 & 2755 & 0.18 & - & $-*$ & + \\
1931.3 & c-4/5 & -43.82 & 2418 & 0.16 & + & + & + \\
2252.5 & IS13 & -41.59 & 440 & 0.23 & + & + & + \\
2254.2 & IS13 & -39.75 & 280 & 0.23 & + & + & + \\
2390.0 & IS16 & -39.72 & 298 & 0.19 & + & + & + \\
2399.9 & c-16/17 & -41.68 & 810 & 0.17 & - & $-*$ & + \\
2708.5 & c-21/22 & -41.76 & 650 & 0.22 & + & - & + \\
2901.5 & c-pre23 & -39.86 & 634 & 0.12 & - & - & - \\
2904.8 & c-pre23 & -39.32 & 502 & 0.16 & + & - & + \\
2918.0 & w-23/5el & -37.34 & 122 & 0.20 & - & - & - \\
2921.3 & c-post5el & -39.32 & 268 & 0.16 & + & - & + \\
& & & & & & & + \\
\hline
\end{tabular}

Notes: All sections are $1.65 \mathrm{~m}$ long. The climatic period is preliminary; it was determined by matching the NorthGRIP dust profile to the GRIP $\delta^{18} \mathrm{O}$ profile (Johnsen and others, 1997). The NorthGRIP $\delta^{18} \mathrm{O}$ values given are from personal communication from NorthGRIP members (2000). hol: Holocene; IS $n$ : GRIP interstadial $n$; c- $m / n$ : cold stadial between IS $m$ and IS $n$; c-pre23: cold stage before IS23; w-23/5el: intermittent warm stage between IS23 and 5el; c-post5el: cold stage after 5el. na: data not available; +: existing; -- not existing; -*: no ECM peak observed but a visible ash layer.

NorthGRIP members, 2000). For some sections, acidity and standard IC anion data are also available and will be included in our discussion. Table 1 gives an overview of all selected sections, many of which contain volcanic horizons.

\section{RESULTS AND DISGUSSION}

\section{The high-resolution profiles}

Articulate variations of the dust concentration are observed throughout large sections of the core. Figure 3 shows two $1.65 \mathrm{~m}$ long sections of the microparticle and $\mathrm{Ca}^{2+}$ profiles, one from the Holocene and one from the LGM. Typical peak heights for microparticles are about 6 times $\left(\mathrm{Ca}^{2+}: 4\right.$ times $)$ the background value in the Holocene and about 2.2 times $\left(\mathrm{Ca}^{2+}: 2.0\right.$ times $)$ the value in the LGM section. Based on a preliminary estimate of annual-layer thicknesses $\lambda$, made by applying the GRIP ages from Johnsen and others (1997) to identified horizons in the NorthGRIP core, we expect that the variations may correspond to annual variations in the Holocene section; in the LGM section partly annual and partly multi-annual variations may be resolved. The insoluble-dust profile, therefore, may assist the dating by annuallayer counting based on other high-resolution profiles, such as ECM, $\mathrm{Ca}^{2+}, \mathrm{Na}^{+}$or visual stratigraphy (e.g. Meese and others, 1997).

\section{Variation of the $\mathrm{Ca}^{2+} /$ dust ratio}

Normally, a good correspondence is observed between insoluble microparticle and $\mathrm{Ca}^{2+}$ concentrations for Holocene ice as well as for glacial-age ice. The correlation coefficients for the two examples shown in Figure 3 are 0.92 (Holocene) and 0.89 (LGM) after slight smoothing of both signals (see below). A similarly high correlation is found throughout the whole core. This at first sight may seem to be a general confirmation for the use of $\mathrm{Ca}^{2+}$ concentrations as a proxy for the insoluble-mineral-dust variability.

A more detailed examination of the $\mathrm{Ca}^{2+}$ /dust ratio reveals, however, distinct differences between the Holocene and the glacial section. To inspect these, the $\mathrm{Ca}^{2+} /$ dust ratio was calculated for each data point and smoothed to weaken artifacts arising from incorrect peak phasings and from different peak shapes caused by signal noise, different sample dispersion or different response characteristics of the two detection systems. For the smoothing, a $5.0 \mathrm{~cm}$ wide hanning window was used, i.e.
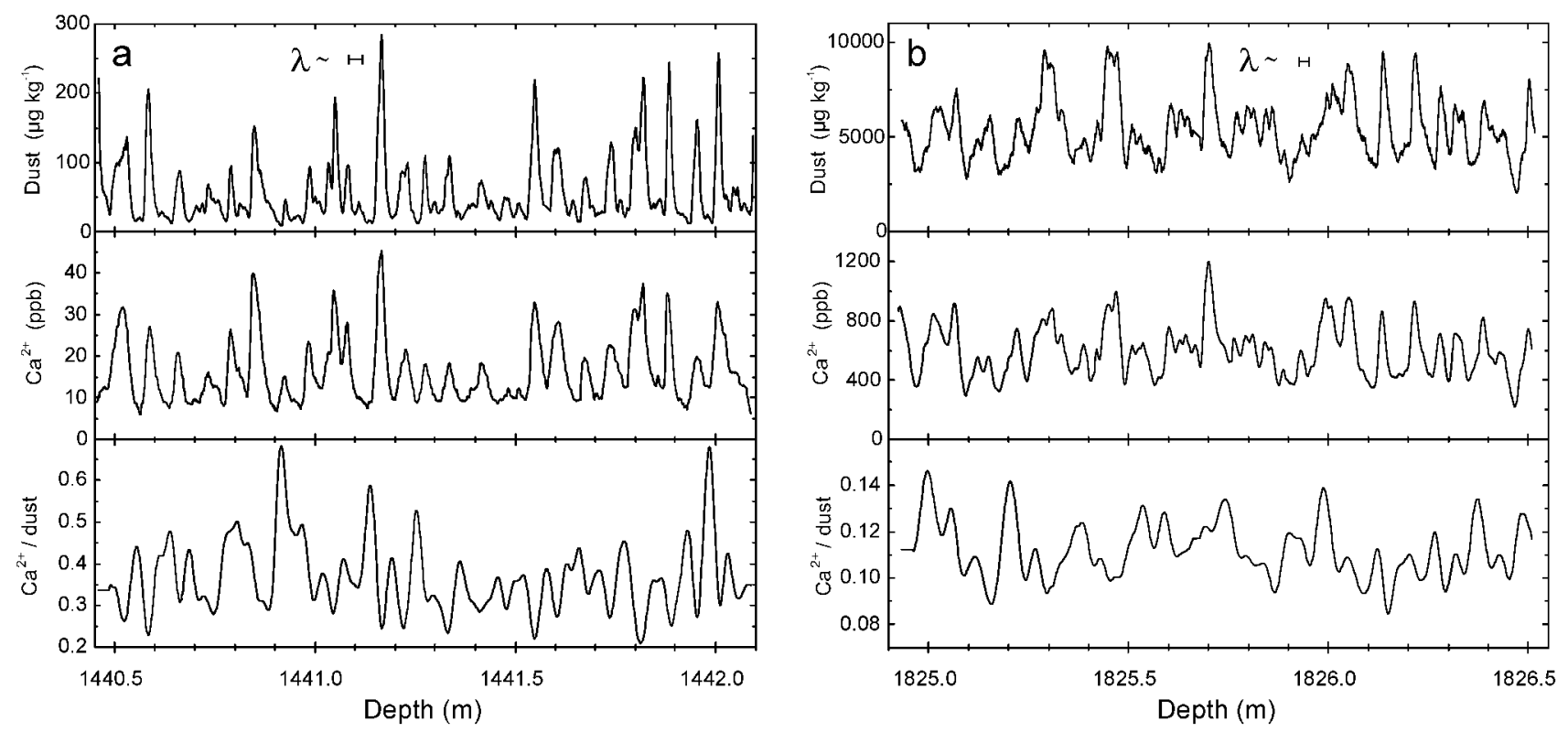

Fig. 3. Examples of the insoluble dust and the $\mathrm{Ca}^{2+}$ measurements: (a) during the Holocene, (b) during the LGM. Also shown is the $\mathrm{Ca}^{2+} /$ dust ratio, which is smoothed (see text). A preliminary estimate of expected annual layer thicknesses $\lambda$ is included. Note the different scales in all panels for $(a)$ and $(b)$. 


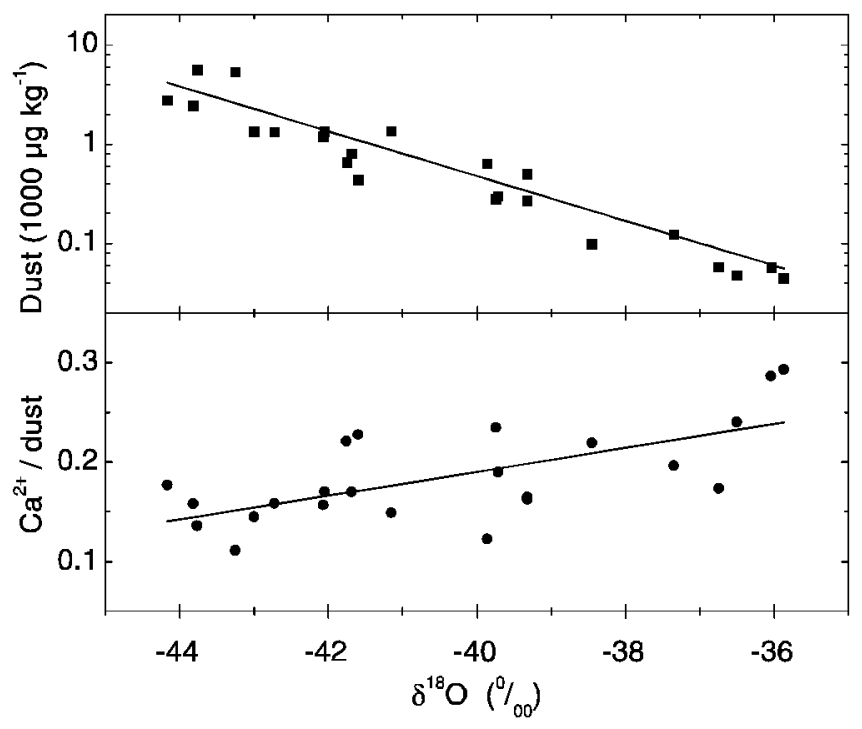

Fig. 4. $\mathrm{Ca}^{2+} /$ dust ratio and mean dust concentration for all 23 sections plotted against $\delta^{18} \mathrm{O}$. Each data point represents a $1.65 \mathrm{~m}$ long interval.

a gliding average using a cosinusoidal weighting function. The smoothed $\mathrm{Ca}^{2+} /$ dust ratio is included in Figure 3. It varies significantly on the same depth scale, as peaks occur in the crustal concentrations, and tends to be enhanced at low dust levels. The (mean $\mathrm{Ca}^{2+}$ )/(mean dust) ratio of the two sections is $\sim 0.29$ for the Holocene and $\sim 0.11$ for the LGM, which is similar to earlier findings by Steffensen (1997) based on established Coulter counter and standard IC measurements.

For all ice-core sections listed in Table 1 , the $\mathrm{Ca}^{2+}$ /dust mean ratios were calculated; hereby horizons with strong acid inputs, which showed unusually high $\mathrm{Ca}^{2+} /$ dust values (see below), were excluded. Figure 4 shows the derived (mean $\left.\mathrm{Ca}^{2+}\right) /\left(\right.$ mean dust) ratios plotted against $\delta^{18} \mathrm{O}$; mean microparticle concentrations are also shown. A gradual trend to lower mean ratios for isotopically colder samples is apparent. It can be excluded that the observed trend is an artifact arising from possibly higher relative errors of the measurements for isotopically warmer samples, which have lower concentrations of $\mathrm{Ca}^{2+}$ and dust; even Holocene concentrations are well above the detection limit, and both systems responded very linearly to sample concentrations. Also the $\mathrm{Ca}^{2+}$ fraction derived from sea-salt aerosol does not contribute significantly.

In order to compare the measured $R_{0}=\left(\mathrm{Ca}^{2+}\right) /($ insoluble dust) ratios with data on the elemental composition of airborne mineral dust or source material, the ratios $R_{0}$ need to be converted to $R=$ (total Ca)/(total dust). That is: $R=a\left\{1 /\left[\left(b R_{0}\right)^{-1}+c\right]\right\}$, where $a=($ total $\mathrm{Ca}) /\left(\mathrm{Ca}^{2+}\right) \approx 1$ is the ratio of total $\mathrm{Ca}$ to dissolved $\mathrm{Ca}^{2+}, b \approx 0.9$ is the correction for the dust fraction not measured below $1.0 \mu \mathrm{m}$, and $c=2.5$ is the mass ratio of $\mathrm{CaCO}_{3}$ to $\mathrm{Ca}$, assuming that the dissolved dust fraction predominantly consisted of $\mathrm{CaCO}_{3}$ or of species with similar mass. This approximation yields ratios of 0.16 for the Holocene and 0.08 for the LGM. This Holocene value is in weak agreement with a mean ratio of 0.09 (range: 0.06-0.18) deduced from measurements of total $\mathrm{Ca}$ and $\mathrm{Al}$ in recent Greenland firn by atomic absorption spectroscopy (Boutron, 1978), but is larger than the value of 0.05 deduced from total $\mathrm{Ca}$ and $\mathrm{Al}$ analyses in Summit aerosol by Colin and others (1997). For comparison to both references, the reported $\mathrm{Al}$ masses were used to infer the total dust mass by assuming a crustal abundance of $8 \%$.
Table 2. Mean weight fractions of $\mathrm{Ca}$ in different types of crust material ( adapted from Bowen, 1978)

$\begin{array}{ll}\text { Mean crust (igneous rocks) } & 0.041 \\ \text { Mean sediment } & 0.066 \\ \text { Marine carbonates } & 0.203 \\ \text { Mean limestone } & 0.340\end{array}$

Soils

$0.015(0.0007-0.50)$

The trend to lower observed values of $\mathrm{Ca}^{2+} /$ dust for lower $\delta^{18} \mathrm{O}$ is a matter of dispute, as several explanations may be invoked. These include possible changes of source areas and properties, or of fractionating transformation and removal processes during long-range transport or deposition (e.g. Hansson, 1994; Wurzler and others, 2000). The observed effect might also be explained by slower dissolution of $\mathrm{Ca}^{2+}$ due to alkaline conditions of glacial-age ice, which would lead to lower observed $\mathrm{Ca}^{2+}$ concentrations using the immediate CFA detection method used here.

Changes of mineral dust source areas are a controversial topic in the literature. De Angelis and others (1997), by comparing their $\mathrm{Ca}^{2+} / \mathrm{Mg}^{2+}$ ratios to Bowen (1979), deduce mean sediment sources for the present day, and marine carbonate sources for the last glacial. Biscaye and others (1997), based on mineralogical and isotopic studies, propose no significant change of source area during times of variable dust fluxes within the last glacial. Hinkley and others (1997), on the basis of mineralogical studies, presume a present-day tropospheric background aerosol uniformly composed of average crustal rock and not of carbonates. Maggi (1997) finds that weathering processes may have changed with climate; but little is known about how this might have affected the relative abundances of $\mathrm{CaCO}_{3}$ or $\mathrm{CaSO}_{4}$ in the dust aerosol (Pye, 1987). A comparison of our data with $\mathrm{Ca}$ abundances in crustal material (Bowen, 1979) (see Table 2) suggests that marine carbonates or limestone sediments contributed significantly only during the Holocene and that during the LGM mean crust and other sediments dominated. Various soils could have contributed at all times.

In the data presented here, the variations of the $\mathrm{Ca}^{2+} /$ dust ratio that occur on an annual to multi-annual scale follow the same pattern as the variations just discussed on a long time-scale. As can be seen in Figure 3, the $\mathrm{Ca}^{2+} /$ dust ratio is small during large dust concentrations, which at least for the Holocene may be driven by variability in the transport efficiency, as known for the Arctic haze phenomenon (Rahn and Borys, 1977). It seems possible that also on an annual time-scale these variations may be attributed to changing source areas or may be closely linked to changing fractionation processes during long-range transport

\section{Special events in the microparticle and $\mathrm{Ca}^{2+}$ profiles}

Figure 5 shows an example of a $1.65 \mathrm{~m}$ long section from the time between GRIP interstadials 1 and 2 which exhibits several anomalies (denoted by $\alpha-\delta$ ). Event $\alpha$ is a strong dust layer (note that the microparticle concentration was cut off by the detector electronics). Event $\delta$ is an increase of the $\mathrm{Ca}^{2+} /$ dust ratio caused by a $\mathrm{Ca}^{2+}$ peak that has no corresponding microparticle peak; only $\mathrm{NO}_{3}^{-}$exhibits a pronounced peak that may be related (e.g. Wolff, 1984). Events $\beta$ and $\gamma$ arise from two very strong $\mathrm{Ca}^{2+}$ peaks coinciding with only small insoluble-dust peaks; they have a $\mathrm{Ca}^{2+}$ /dust ratio 


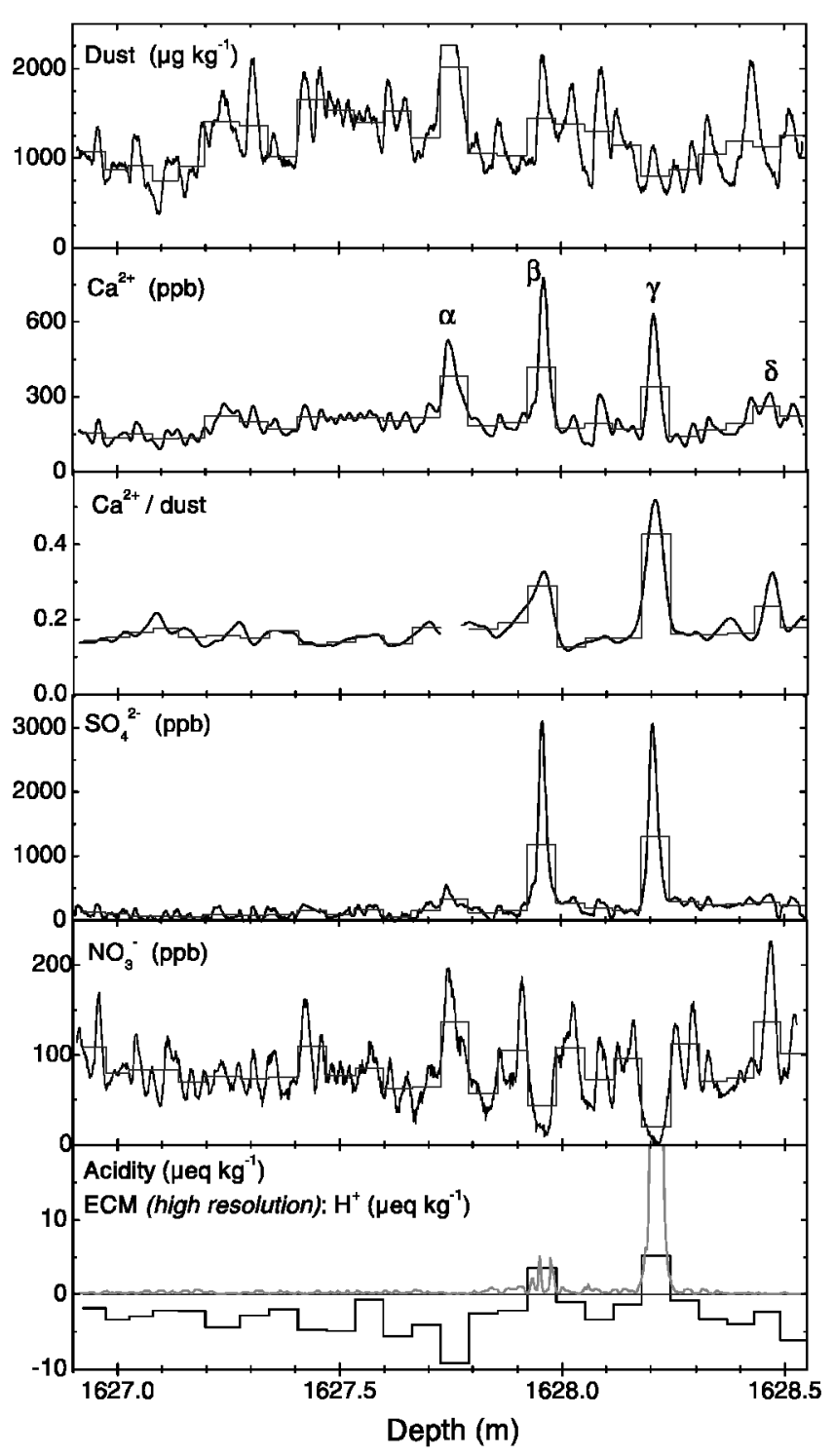

Fig. 5. Examples of anomalous events in the microparticle and $\mathrm{Ca}^{2+}$ profiles. The sample is from the cold stadial between interstadials 1 and 2. The data for dust, $\mathrm{Ca}^{2+}, \mathrm{SO}_{4}{ }^{2-}$ and $\mathrm{NO}_{3}^{-}$were obtained by $\mathrm{CFA}$; the $\mathrm{Ca}^{2+} /$ dust ratio was smoothed (see text); acidity was measured at approximately $6 \mathrm{~cm}$ depth resolution; in the same panel the ECM data are shown in high resolution (preliminary calibration). The fine histogram-style lines represent the high-resolution data reduced to the resolution of the acidity measurement. Labelled $\mathrm{Ca}^{2+}$ peaks refer to events discussed in text.

about $100 \%$ and $200 \%$ higher than the typical value. Coinciding are very strong peaks in $\mathrm{SO}_{4}{ }^{2-}$ and also enhancements of ECM, acidity and $\mathrm{F}^{-}$(not shown) indicating volcanic horizons. These phenomena were observed mainly during cold glacial times, but also occurred during warm interstadials.

From our size-distribution measurements we can rule out that the observed increase of the $\mathrm{Ca}^{2+} /$ dust ratio during events $\beta$ and $\gamma$ is only an artifact resulting from a dust size distribution severely shifted towards larger particles during these events. High inputs of acid, however, may lead to enhanced $\mathrm{Ca}^{2+}$ /dust ratios by promoting the rapid dissolution of calcite particles or $\mathrm{CaCO}_{3}$ coatings. Indeed, all 13 anomalous $\mathrm{Ca}^{2+}$ /dust enhancements investigated in this study are accompanied by a clear $\mathrm{SO}_{4}{ }^{2-}$ peak, indicating a strong input of acid (see Table 1).

An ionic balance was evaluated using major-ion concen- trations and acidity data for 10 of these sections, and it was found to be rather constant - not zero, at a low $\mu \mathrm{eq} \mathrm{kg}^{-1}$ level - across the disturbed horizons, which indicates that no unmeasured ionic species contributed substantially during these events. From the ionic balance, of course, it still cannot be distinguished to what extent $\mathrm{SO}_{4}{ }^{2-}$ derived from $\mathrm{H}_{2} \mathrm{SO}_{4}$ or from mineral $\mathrm{CaSO}_{4}$. But it seems much more probable that during volcanic events $\mathrm{SO}_{4}{ }^{2-}$ originates mainly from volcanic $\mathrm{H}_{2} \mathrm{SO}_{4}$ and that the $\mathrm{Ca}^{2+}$ peak is produced by enhanced dissolution of $\mathrm{CaCO}_{3}$ during in-cloud processing or pre-analytical sample melting.

\section{GONGLUSIONS}

The novel particle sensor proved to be a reliable tool even under field conditions; it provided the total particle concentration at $\leq 1 \mathrm{~cm}$ depth resolution backed up by size-distribution information. Thus, calibrated records of insoluble-particle mass concentrations are obtained. Variations of the $\mathrm{Ca} / \mathrm{dust}$ mass ratio were seen during long-term climatic changes, as well as on annual or multi-annual time-scales. This suggests variable source properties or variable fractionation during transfer, which should be investigated in more detail. If $\mathrm{Ca}^{2+}$ measurements are used as a quantitative proxy for mineral dust, care must be taken when considering data across climatic transitions, at volcanic horizons or at subseasonal resolution.

A dedicated investigation of Ca ion solubility in glacial-age meltwater and its implications for the CFA and IC analytical methods is essential as we are currently limited in our interpretation by this uncertainty. To elucidate possible variations in dust source areas and properties, or changes in fractionation processes during long-range transport, routine analyses of crustal reference elements like $\mathrm{Al}$ are needed, as they would help to infer the total, i.e. soluble and insoluble, crustal concentration.

\section{ACKNOWLEDGEMENTS}

The NorthGRIP project is directed and organized by the Department of Geophysics at the Niels Bohr Institute for Astronomy, Physics and Geophysics, University of Copenhagen. It is supported by funding agencies in Denmark, Belgium, France, Germany, Iceland, Japan, Sweden, Switzerland and the United States of America. We wish to thank all the funding bodies and field participants. C. M. Zdanowicz is thanked for his helpful comments to improve the manuscript.

\section{REFERENGES}

Armbruster, M. 2000. Stratigraphische Datierung hoch-alpiner Eisbohrkerne über die letzten 1000 Jahre. (M.Sc. thesis, Universität Heidelberg. Institut für Umweltphysik.)

Biscaye, P. E. and 6others. 1997. Asian provenance of glacial dust (stage 2) in the Greenland Ice Sheet Project 2 ice core, Summit, Greenland. 7. Geophys. Res., 102(C12), 26,765-26,781.

Boutron, C. 1978. Influence des aérosols d'origines naturelle et anthropogénique sur la chimie des neiges polaires. (Ph.D. thesis, Université de Grenoble.

Bowen, H.J. M. 1979. Environmental chemistry of the elements. London, Academic Press.

Colin, J.L. and 6 others. 1997. Air-to-snow mineral transfer-crustal elements in aerosols, fresh snow and snowpits on the Greenland ice sheet. Atmos. Environ., 31 (20), 3395-3406.

De Angelis, M., J.-P. Steffensen, M. Legrand, H. Clausen and C. Hammer. 1997. Primary aerosol (sea salt and soil dust) deposited in Greenland ice during the last climatic cycle: comparison with East Antarctic records. f. Geophys. Res., 102(C12), 26,681-26,698. 
Fuhrer, K., E. W. Wolff and S. J. Johnsen. 1999. Timescales for dust variability in the Greenland Ice Core Project (GRIP) ice core in the last 100,000 years. 7. Geophys. Res., 104(D24), 31,043-31,052.

Hammer, C. U., H. B. Clausen, W. Dansgaard, A. Neftel, P. Kristinsdóttir and E. Johnson. 1985. Continuous impurity analysis along the Dye 3 deep core. In Langway, C. C., Jr, H. Oeschger and W. Dansgaard, eds. Greenland ice core: geophysics, geochemistry, and the environment. Washington, DC, American Geophysical Union, 90-94. (Geophysical Monograph 33 .

Hansson, M. E. 1994. The Renland ice core: a Northern Hemisphere record of a erosol composition over 120000 years. Tellus, 46B(5), 390-418.

Hinkley, T. K., F. Pertsiger and L. Zavjalova. 1997. The modern atmospheric background dust load: recognition in central Asian snowpack and compositional constraints. Geophys. Res. Lett., 24(13), 1607-1610.

Johnsen, S. J. and 14 others. 1997. The $\delta^{18} \mathrm{O}$ record along the Greenland Ice Core Project deep ice core and the problem of possible Eemian climatic instability. F. Geophys. Res., 102(C12), 26,397-26,410.

Maggi, V. 1997. Mineralogy of atmospheric microparticles deposited along the Greenland Ice Core Project ice core. 7. Geophys. Res., 102(C12), $26,725-26,734$

Meese, D. A. and 8 others. 1997. The Greenland Ice Sheet Project 2 depth-age scale: methods and results. F. Geophys. Res., 102(C12), 26,411-26,423.

Petit, J.-R. and 18 others. 1999. Climate and atmospheric history of the past 420,000 years from the Vostok ice core, Antarctica. Nature, 399(6735), 429-436.

Pye, K. 1987. Aeolian dust and dust deposits. London, Academic Press.
Rahn, K. A. and R. D. Borys. 1977. The Asian source of Arctic haze bands. Nature, 268(5622), 713-715.

Ram, M. and G. Koenig. 1997. Continuous dust profile of pre-Holocene ice from the Greenland Ice Sheet Project 2 ice core: dust stadials, interstadials, and the Eemian. F. Geophys. Res., 102(C12), 26,641-26,648.

Röthlisberger, R. and 6 others. 2000. Technique for continuous high-resolution analysis of trace substances in firn and ice cores. Environ. Sci. Technol., 34(2), 338-342.

Saey, P. 1998. Konzentration und Größenverteilung von Mikropartikeln in alpinen und polaren Eisbohrkernen. (M.Sc. thesis, Universität Heidelberg. Institut für Umweltphysik.

Steffensen, J. P. 1997. The size distribution of microparticles from selected segments of the GRIP ice core representing different climatic periods. 7. Geophys. Res., 102(C12), 26,755-26,763.

Taylor, K. C., R. B. Alley, G. W. Lamorey and P. A. Mayewski. 1997. Electrical measurements on the Greenland Ice Sheet Project 2 core. 7. Geophys. Res., 102(C12), 26,511-26,517.

Tegen, I. and I. Fung. 1994. Modeling of mineral dust in the atmosphere: sources, transport, and optical thickness. 7. Geophys. Res., 99(D11), $22,897-22,914$

Wolff, G.T. 1984. On the nature of nitrate in coarse continental aerosols Atmos. Environ., 18(5), 977-981.

Wurzler, S., T. G. Reisin and Z. Levin. 2000. Modification of mineral dust particles by cloud processing and subsequent effects on drop size distributions. F. Geophys. Res., 105(D4), 4501-4512. 